\title{
Leptin levels in women with polycystic ovary syndrome before and after treatment with diazoxide
}

\author{
G E Krassas, T T Kaltsas, N Pontikides, H Jacobs ${ }^{1}$, W Blum ${ }^{2}$ and I Messinis ${ }^{3}$ \\ Endocrine Clinic, Panagia Hospital, Thessaloniki, Greece, ${ }^{1}$ Cobbold Laboratory, The Middlesex Hospital, London, UK, ${ }^{2}$ Lilly Deutschland GmbH, \\ 61350 Bad Homburg, Germany and ${ }^{3}$ Department of Obstetrics and Gynaecology, University of Thessalia, Greece \\ (Correspondence should be addressed to G Krassas, Tsimiski 92, Thessaloniki, Greece)
}

\begin{abstract}
Leptin, a product of the $o b$ gene, is a $16 \mathrm{kDa}$ protein which is produced by adipocytes. In humans, obesity is a common finding in women with polycystic ovary syndrome (PCOS). The role, however, of leptin in PCOS is not clear. Some studies have reported increased levels of leptin in PCOS, while others report that they are normal. Also, insulin resistance is a common finding in PCOS. The aim of this study was to investigate further the role of insulin in leptin secretion in patients with PCOS by treating them for 10 days with diazoxide, an insulin-reducing compound.

Eight women with PCOS, mean age $22.1 \pm 2.7$ years, with mean body mass index (BMI) $28.4 \pm 5.7 \mathrm{~kg} / \mathrm{m}^{2}$, were studied. An oral glucose tolerance test (OGTT) was performed in all women and blood samples were taken before and at 30,60, 90, 120 and 150 min after the administration of glucose. Glucose, insulin, leptin, free testosterone, $\Delta 4$ androstenedione, sex hormone binding globulin (SHBG), LH, FSH, IGF-I and insulin-like growth factor-binding protein-3 (IGFBP-3) were measured in the sera taken before the administration of glucose, while glucose and insulin levels were measured in all samples which were collected after the administration of glucose. Diazoxide $300 \mathrm{mg}$ daily was given to all women starting after the end of the OGTT for 10 days. A second OGTT was performed the day after the discontinuation of the diazoxide treatment. The same hormonal and biochemical parameters were also measured in all patients during the second OGTT.

After the administration of diazoxide a reduction in sum insulin $(262 \pm 147 \mathrm{vs} 679 \pm 341 \mu \mathrm{U} / \mathrm{ml}$, $P<0.01)$, leptin $(18.5 \pm 10.6$ vs $24.2 \pm 10.2 \mathrm{ng} / \mathrm{ml}, P<0.01)$, free testosterone $(3.0 \pm 1.9$ vs $5.1 \pm 1.9 \mathrm{pg} / \mathrm{ml}, P<0.01), \Delta 4$ androstenedione $(3.8 \pm 1.9$ vs $5.7 \pm 2.0 \mathrm{ng} / \mathrm{ml}, P<0.01)$ and IGF-I $(219.5 \pm 69.2$ vs $314.5 \pm 82.3 \mathrm{ng} / \mathrm{ml}, P<0.01)$ levels was observed. Serum SHBG $(38.8 \pm 16.8$ vs $27.8 \pm 12.1 \mathrm{nmol} / \mathrm{l}, P<0.01)$ and sum glucose levels $(994.1 \pm 252.7 \mathrm{vs} 711.1 \pm 166.1 \mathrm{mg} / \mathrm{dl}$, $P<0.05)$ were increased while IGFBP-3 $(3.96 \pm 2.49$ vs $3.75 \pm 2.24 \mathrm{mg} / \mathrm{l})$, FSH $(6.2 \pm 1.8$ vs $6.0 \pm 2.5 \mathrm{mU} / \mathrm{l})$ and $\mathrm{LH}(18.9 \pm 6.7 \mathrm{vs} 21.4 \pm 6.7 \mathrm{mU} / \mathrm{l})$ concentrations did not change significantly. A significant positive correlation was found between serum leptin and BMI values before and after administration of diazoxide as well as between leptin, insulin and IGFBP-3 values. Also, sum insulin values correlated significantly with BMI. However, when multiple regression analysis was used this correlation was eliminated except that between leptin and BMI. This was most probably due to the small number of cases. The mechanism of the reduction of leptin levels is unclear. However, it is suggested that the concomitant decrease of insulin levels may play a role.
\end{abstract}

European Journal of Endocrinology 139 184-189

\section{Introduction}

Leptin, a product of the $o b$ gene, is a $16 \mathrm{kDa}$ protein which is produced by adipocytes (1). This protein regulates fat stores and hence body weight by affecting appetite and thermogenesis (2). The first indication that leptin may have additional functions came from studies in $o b / o b$ mice, which become obese because they lack leptin. The injection of leptin into these animals reduces fat tissue and body weight and restores fertility (3-5). It is assumed, therefore, that leptin may act as a linkage between adipose tissue function and reproduction in rodents. In humans, obesity is a common finding in women with polycystic ovary syndrome (PCOS). The role, however, of leptin in PCOS is not clear. A recent study has reported that women with PCOS may have increased levels of leptin compared with normal controls (6). Subsequent studies, however, have shown that leptin levels in PCOS women do not differ from those in normal subjects $(7-10)$. In these studies significant positive correlations were found between leptin levels and body mass index (BMI). Although insulin also correlated significantly with leptin and BMI, there is some evidence that insulin may affect leptin production independently of BMI (8). On the other hand, insulin can affect ovarian cell function and 
ovarian production of androgens (11), while insulin resistance is a common finding in PCOS (12). The purpose of this study was to examine further the role of insulin in the secretion of leptin in patients with PCOS, by treating them with diazoxide. We chose diazoxide because it is a potent insulin-reducing compound, which for this reason is now used in clinical practice for the treatment of insulinomas (13).

\section{Patients and methods}

Eight women with PCOS, 20-28 years old (mean age $22.1 \pm 2.7$ s.D.), with BMI $19.7-38.2 \mathrm{~kg} / \mathrm{m}^{2}$ (mean $28.4 \pm 5.7$ ) were studied (Table 1). Clinical diagnosis of PCOS was based on the presence of oligomenorrhoea of perimenarcheal onset and hirsutism. All women had hyperandrogenaemia, elevated luteinizing hormone (LH), and the typical ultrasound appearances of PCOS (ten or more cysts $2-8 \mathrm{~mm}$ in diameter, associated with an increase in ovarian stroma) (14). None of the women had used any hormonal or other medication during the 3 months prior to the onset of the study. Approval for the study was obtained from the local Ethical Committee and all patients gave written informed consent.

An oral glucose tolerance test (OGTT) using $75 \mathrm{~g}$ glucose was performed in all women after an overnight fast at $0900 \mathrm{~h}$ on day 2 following a spontaneous or a progesterone-induced menstrual period. Blood samples were taken before and 30,60, 90, 120 and $150 \mathrm{~min}$ after the administration of glucose. Sera were obtained by centrifugation, immediately frozen and stored at $-20^{\circ} \mathrm{C}$ until further analysis.

Glucose, insulin, leptin, free testosterone, $\Delta 4$ androstenedione, sex hormone binding globulin (SHBG), LH, follicle-stimulating hormone (FSH), insulin-like growth factor-I (IGF-I), and insulin-like growth factor-binding protein-3 (IGFBP-3) were measured in the blood samples taken before the administration of glucose, while glucose and insulin levels were measured in all samples which were collected after the administration of glucose.

Diazoxide at a daily dose of $300 \mathrm{mg}$ was given to all women for 10 days, while they were on a standard diet, starting after the end of the OGTT. A second OGTT was performed the day after the discontinuation of the

Table 1 Characteristics of eight patients with PCOS.

\begin{tabular}{lll}
\hline No. & Age (years) & BMI $\left(\mathrm{kg} / \mathrm{m}^{2}\right)$ \\
\hline 1 & 21 & 19.7 \\
2 & 22 & 24.5 \\
3 & 20 & 26.3 \\
4 & 20 & 28.3 \\
5 & 22 & 28.9 \\
6 & 28 & 38.2 \\
7 & 24 & 26.9 \\
8 & 20 & 34.6 \\
Mean \pm S.D. & $22.1 \pm 2.7$ & $28.4 \pm 5.7$ \\
\hline
\end{tabular}

diazoxide treatment. The same hormonal and biochemical parameters were also measured in all patients during the second OGTT.

\section{Hormone assays}

Serum leptin was measured by a specific RIA, as described in detail elsewhere (15). In brief, recombinant human leptin (a gift from Dr Heiman, Eli Lilly Research Laboratories, Indianapolis, IN, USA) was used for the generation of antiserum in rabbits, and for the preparation of tracer by the chloramine-T method and for standards. The assay buffer was composed of $0.05 \mathrm{~mol} / \mathrm{l}$ sodium phosphate, $\mathrm{pH} 7.4,0.1 \mathrm{~mol} / \mathrm{l} \mathrm{NaCl}$, $0.1 \%(\mathrm{vol} / \mathrm{vol})$ gelatin from teleost fish (Sigma Chemicals, Munich, Germany), 0.1\% (vol/vol) Triton X 100 (Serva, Heidelbeg, Germany) and $0.05 \%$ (vol $/ \mathrm{vol}$ ) $\mathrm{NAN}_{3}$. The assay volume was $0.3 \mathrm{ml}$. After incubation at room temperature overnight bound and unbound tracer were separated by a second antibody technique. Maximal tracer binding was $37-45 \%$ and half-maximal binding occurred at $0.9 \mu \mathrm{g} / \mathrm{l}$ unlabelled leptin.

Excellent parallelism was obtained with serial dilutions of human serum, and spiking experiments with $0.1 \mathrm{ng}$ per tube yielded a recovery of $97 \pm 2 \cdot 1 \%$. Sensitivity was $0.03 \mu \mathrm{g} / \mathrm{l}$ and the intra- and interassay coefficients of variation were 0.8 and $8.5 \%$ respectively. Mean \pm s.D. leptin values in 30 healthy, non-pregnant women of reproductive age were $7.2 \pm 6.1 \mathrm{ng} / \mathrm{ml}$.

Insulin was measured by RIA using a CIS BioInternational Kit (Paris, France). The results are expressed as $\mu \mathrm{U} / \mathrm{ml}$. The lower limit of detection for insulin was $3.6 \mu \mathrm{U} / \mathrm{ml}$ while the intra- and interassay coefficients of variation were 6.4 and $6.9 \%$ respectively.

IGF-I concentrations were measured by RIA following acid-ethanol extraction. Kits were purchased from Nichols Institute, San Juan Capistrano, CA, USA. The intra- and interassay coefficients of variation were 4.4 and $5.8 \%$ respectively and the results are expressed as $\mathrm{ng} / \mathrm{ml}$. IGFBP-3 measurements were performed by RIA using a specific competitive protein-binding immunoassay with kits from Nichols Institute. The intra- and interassay coefficients of variation were 5.2 and $6.1 \%$ respectively and the results are expressed as $\mathrm{mg} / \mathrm{l}$.

SHBG was measured by IRMA. Kits were purchased from RADIM, Liege, Belgium. The intra- and interassay coefficients of variation were 5.1 and $5.9 \%$ respectively and the results are expressed as nmol/l.

Serum FSH and LH were measured using IRMA based on enhanced luminescence (Amerlite FSH assay and Amerlite LH-30 assay respectively). Kits were purchased from Amersham International plc, Amersham, Bucks, UK. The lower limits of detection for FSH and LH were $0.5 \mathrm{mU} / \mathrm{l}$ and $0.12 \mathrm{mU} / \mathrm{l}$ respectively, while intra- and interassay coefficients of variation were 5.9 and $7.5 \%$ and 6.8 and $9.0 \%$ respectively.

Free testosterone was measured by RIA using a coatA-count kit from Diagnostic Products Corporation, Los 
Angeles, CA, USA. The results are expressed as pg/ml. $\Delta 4$ Androstenedione was measured by RIA using a RADIM Kit (Milan, Italy). The results are expressed as $\mathrm{ng} / \mathrm{ml}$. The lower limits of detection for free testosterone and $\Delta 4$ androstenedione were $0.15 \mathrm{pg} / \mathrm{ml}$ and $0.1 \mathrm{ng} /$ $\mathrm{ml}$ respectively, while intra- and interassay coefficients of variation were 5.1 and $7.6 \%$ and 7.2 and $8.1 \%$ respectively.

Glucose levels were determined by the glucose oxidase technique.

\section{Statistical analysis}

The glucose and insulin levels in response to OGTT before and after the administration of diazoxide were estimated by summing the values of all the samples which were taken during the OGTT (sum glucose and sum insulin levels).

A paired $t$-test was used for the comparison of hormonal results before and after diazoxide administration. Relationships between leptin and other variables were calculated by simple and multiple linear regression analysis. For the statistical analysis, the statistical package SPSS for Windows 95 (Ref. 7.5) was used. Data are expressed as means \pm s.D. The level of statistical significance was $P<0.05$.

\section{Results}

Serum concentrations of various biochemical and hormonal parameters before and after treatment with diazoxide are shown in Table 2. After the administration of diazoxide, sum insulin, leptin, free testosterone, $\Delta 4$ androstenedione and IGF-I levels were reduced. The reduction was statistically significant $(P<0.01)$. In particular, leptin values decreased from $24.2 \pm 10.2 \mathrm{ng} /$ $\mathrm{ml}$ before treatment to $18.5 \pm 10.6 \mathrm{ng} / \mathrm{ml}$ after treatment and sum insulin from $679 \pm 341 \mu \mathrm{g} / \mathrm{ml}$ to
$262 \pm 147 \mu \mathrm{g} / \mathrm{ml}$. Before treatment with diazoxide, serum leptin values in all patients studied were above the normal level, defined in this study according to the reference values of the method used for leptin measurement. In all eight patients but two, who were obese, basal insulin levels were within the normal range. The two obese patients had elevated basal insulin values. All patients had normal blood glucose values before treatment with diazoxide, but after treatment sum glucose values increased significantly $(711.1 \pm 166$ to $994.1 \pm 252.7 \mathrm{mg} / \mathrm{dl}, P<0.05)$. The same was found for SHBG $(27.8 \pm 12.1$ to $38.8 \pm 16.8 \mathrm{nmol} / \mathrm{l}, P<0.01)$ (Table 2). IGFBP-3, FSH and LH concentrations did not change significantly after the administration of diazoxide compared with the values before treatment $(3.75 \pm 2.24$ to $3.96 \pm 2.49 \mathrm{mg} / \mathrm{l}, \quad 6.0 \pm 2.5$ to $6.2 \pm 1.8 \mathrm{mU} / \mathrm{l}$ and $21.4 \pm 6.7$ to $18.9 \pm 6.7 \mathrm{mU} / \mathrm{l}$ respectively (Table 2). Weight and BMI increased during the period of administration of diazoxide from $72.6 \pm 15.7$ to $74.5 \pm 15.8 \mathrm{~kg}$ and from $28.4 \pm 5.7$ to $29.2 \pm 5.7 \mathrm{~kg} / \mathrm{m}^{2}$ respectively $(P<0.001)$ (Table 2$)$. In Fig. 1 BMI, IGF-I, IGFBP-3, free testosterone, sum insulin and leptin levels in each individual are presented before and after administration of diazoxide, while in Fig. 2 the mean percentage changes ( \pm S.D.) are shown. Significant positive correlations were found between serum leptin and BMI, sum insulin and IGFBP-3 values before $(P<0.05)$ and after the administration of diazoxide $(P<0.001$ for BMI, $<0.05$ for sum insulin and $P<0.01$ for IGFBP-3) (Table 3 ).

Furthermore, sum insulin values correlated significantly with BMI $(r=0.770, P<0.05)$. A negative, but not significant correlation was found between leptin concentrations and FSH $(r=-0.604)$ or $\mathrm{LH}$ values $(r=-0.598)$ before the administration of diazoxide. No significant correlations were found between leptin and androgens, SHBG or IGF-I values (Table 3). When multiple regression analysis was performed BMI turned

Table 2 BMI, weight and serum values of glucose and hormonal parameters (mean \pm S.D.) before and after administration of diazoxide ( $300 \mathrm{mg}$ daily) for 10 days in eight PCOS patients.

\begin{tabular}{lccc}
\hline & Before treatment & After treatment & $P$ \\
\hline BMl $\left(\mathrm{kg} / \mathrm{m}^{2}\right)$ & $28.4 \pm 5.7$ & $29.2 \pm 5.7$ & $<0.001$ \\
Weight $(\mathrm{kg})$ & $72.6 \pm 15.7$ & $74.5 \pm 15.8$ & $<0.001$ \\
IGF-I $(\mathrm{ng} / \mathrm{ml})$ & $314.5 \pm 82.3$ & $219.5 \pm 69.2$ & $<0.01$ \\
IGFBP-3 $(\mathrm{mg} / \mathrm{l})$ & $3.75 \pm 2.24$ & $3.96 \pm 2.49$ & $\mathrm{NS}$ \\
Free testosterone $(\mathrm{pg} / \mathrm{ml})$ & $5.1 \pm 1.9$ & $3.0 \pm 1.9$ & $<0.01$ \\
Sum glucose $(\mathrm{mg} / \mathrm{dll})$ & $711.1 \pm 166.1$ & $994.1 \pm 252.7$ & $<0.05$ \\
Sum insulin $(\mu \mathrm{U} / \mathrm{ml})$ & $679 \pm 341$ & $262 \pm 147$ & $<0.01$ \\
$\Delta 4$ Androstenedione & $5.7 \pm 2.0$ & $3.8 \pm 1.9$ & $<0.01$ \\
SHBG $(\mathrm{nmol} / \mathrm{l})$ & $27.8 \pm 12.1$ & $38.8 \pm 16.8$ & $<0.01$ \\
Leptin $(\mathrm{ng} / \mathrm{ml})$ & $24.2 \pm 10.2$ & $18.5 \pm 10.6$ & $<0.01$ \\
LH $(\mathrm{mU} / \mathrm{l})$ & $21.4 \pm 6.7$ & $18.9 \pm 6.7$ & $\mathrm{NS}$ \\
FSH $(\mathrm{mU} / \mathrm{l})$ & $6.0 \pm 2.5$ & $6.2 \pm 1.8$ & $\mathrm{NS}$ \\
\hline
\end{tabular}

Normal range: IGF-I 182-492 ng/ml, IGFBP-3 1.82-5.69 mg/l, free testosterone 0.5-3.2 pg/ $\mathrm{ml}, \Delta 4$ androstenedione $0.21-3.08 \mathrm{ng} / \mathrm{ml}$, SHBG $20-80 \mathrm{nmol} / \mathrm{l}$, leptin (see text), LH (secretory phase) $1-18 \mathrm{mU} / \mathrm{l}, \mathrm{FSH}$ (secretory phase) $1-9 \mathrm{mU} / \mathrm{l}$. 

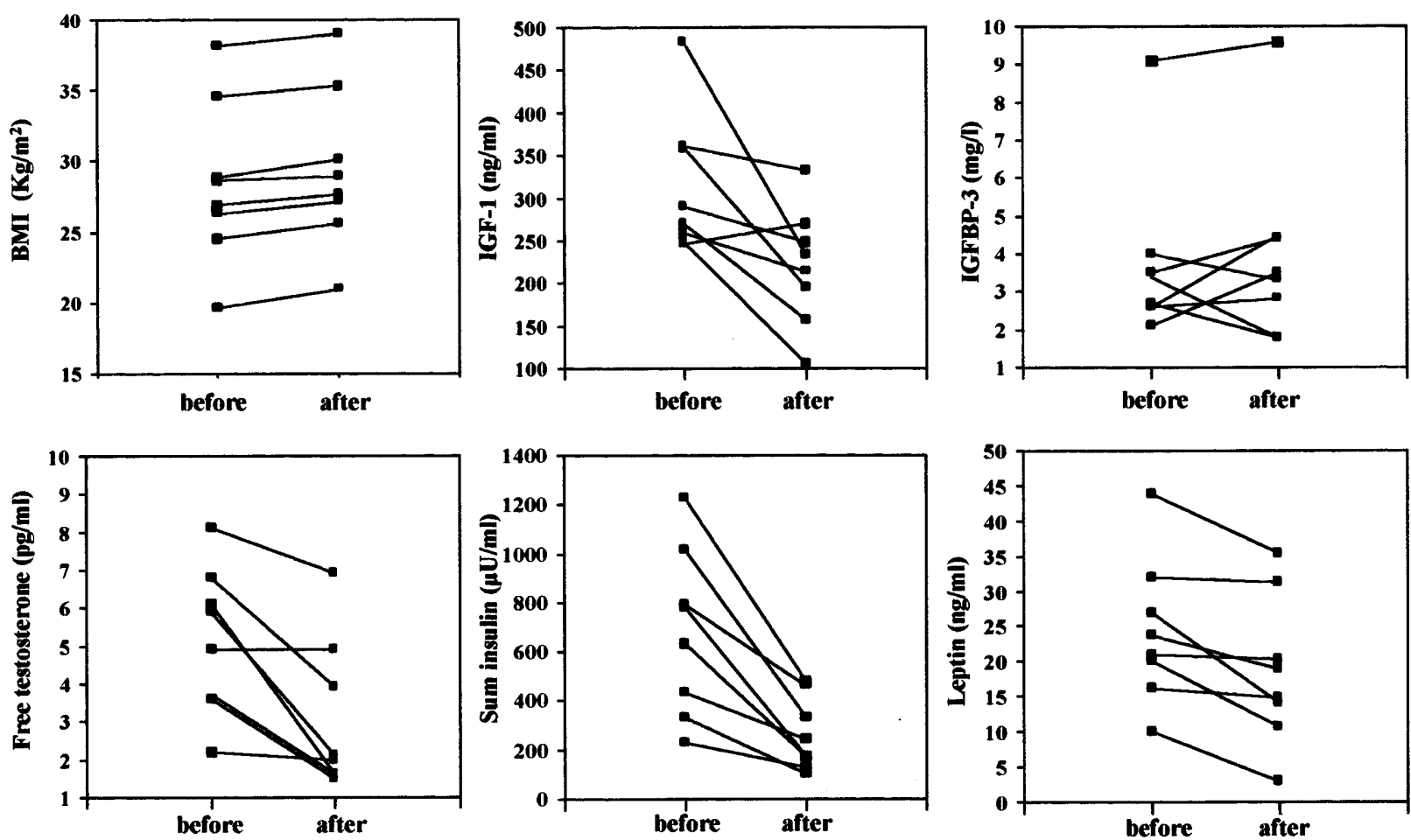

Figure $1 \mathrm{BMI}$ and IGF-I, IGFBP-3, free testosterone, sum insulin and leptin levels before and after administration of diazoxide for 10 days in eight PCOS patients.

out to be the only variable significantly correlating with leptin.

\section{Discussion}

The results of the present study demonstrate a significant decrease in serum concentrations of leptin in women with PCOS after treatment with diazoxide for 10 days. The reasons for the decrease in leptin values are not clear. From a clinical point of view, diazoxide is used as an insulin-reducing agent in patients suffering from hyperinsulinaemic hypoglycaemia. Administration of diazoxide to women with PCOS in this study was also followed by a significant reduction in serum

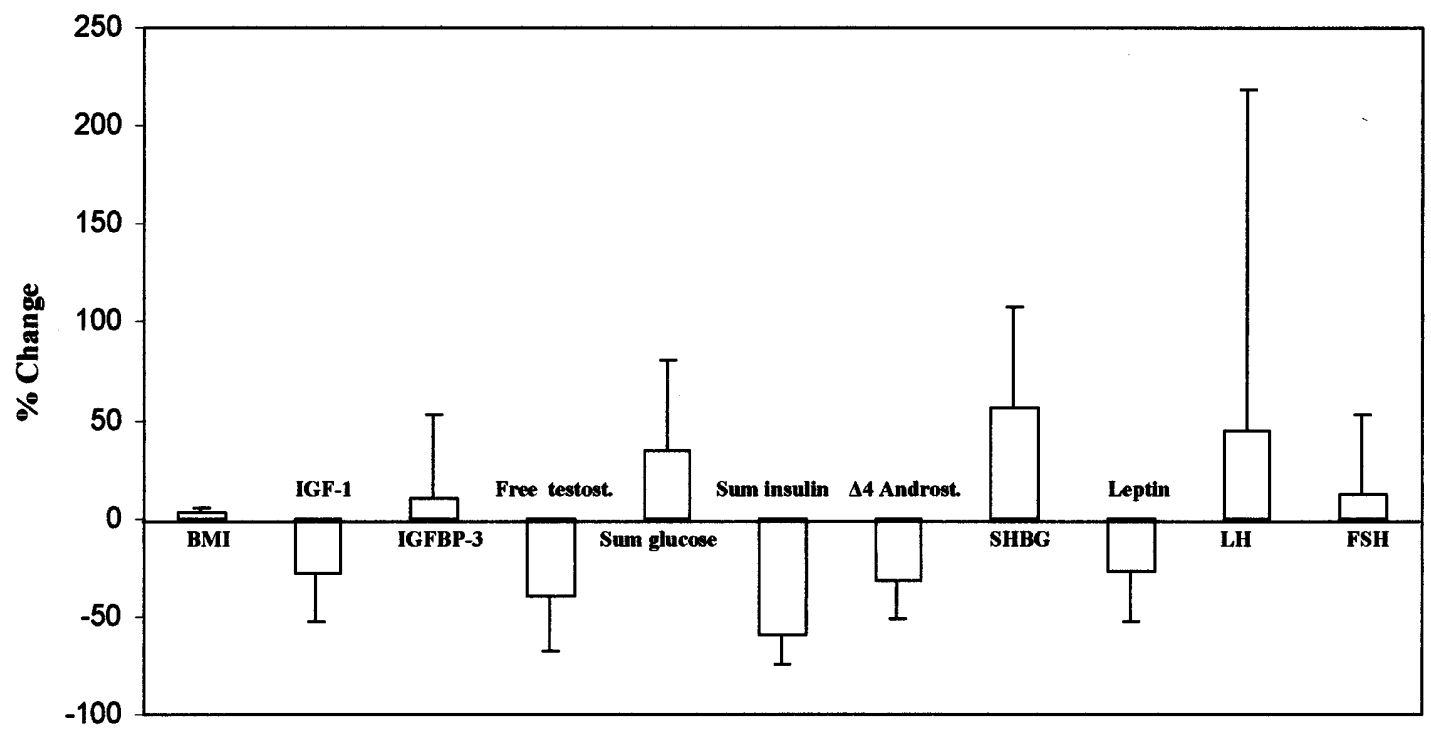

Figure 2 Mean \pm s.D. percentage changes from baseline of parameters investigated after the administration of diazoxide for 10 days in eight PCOS patients. 
Table 3 Correlation coefficient between leptin values and other parameters in women with PCOS before and after treatment with diazoxide.

\begin{tabular}{lcccc}
\hline & Before treatment & $\boldsymbol{P}$ & After treatment & $\boldsymbol{P}$ \\
\hline BMI $\left(\mathrm{kg} / \mathrm{m}^{2}\right)$ & 0.782 & $<0.05$ & 0.933 & $<0.001$ \\
Sum insulin $(\mu \mathrm{U} / \mathrm{ml})$ & 0.728 & $<0.05$ & 0.725 & $<0.05$ \\
IGFBP-3 $(\mathrm{mg} / \mathrm{l})$ & 0.759 & $<0.05$ & 0.837 & $<0.01$ \\
FSH $(\mathrm{mU} / \mathrm{l})$ & -0.604 & $\mathrm{NS}$ & -0.350 & $\mathrm{NS}$ \\
LH $(\mathrm{mU} / \mathrm{l})$ & -0.598 & $\mathrm{NS}$ & -0.152 & $\mathrm{NS}$ \\
Free testosterone $(\mathrm{pg} / \mathrm{ml})$ & 0.560 & $\mathrm{NS}$ & 0.542 & $\mathrm{NS}$ \\
$\Delta 4$ Androstenedione $(\mathrm{ng} / \mathrm{ml})$ & 0.082 & $\mathrm{NS}$ & 0.198 & $\mathrm{NS}$ \\
SHBG $(\mathrm{nmol} / \mathrm{l})$ & 0.164 & $\mathrm{NS}$ & -0.264 & $\mathrm{NS}$ \\
IGF-1 $(\mathrm{ng} / \mathrm{ml})$ & -0.547 & $\mathrm{NS}$ & 0.174 & \\
\hline
\end{tabular}

insulin values (Fig. 1). It could be assumed, therefore, that the reduction in leptin values after diazoxide administration was the result of the decrease in insulin concentrations. Previous studies have shown that insulin may play a role in the regulation of leptin secretion from the adipocytes. For example, insulin can stimulate the expression of mRNA of leptin in human adipose tissue in vitro (16) as well as in rat adipocytes after short-term insulin infusion (17). It has also been shown that increasing serum insulin levels for a short period of time $(5 \mathrm{~h})$ either postprandially or after infusion of insulin does not influence the secretion of leptin in humans $(16,18,19)$, while prolonged hyperinsulinaemia $(>72 \mathrm{~h})$, as a result of a $72 \mathrm{~h}$ hyperglycaemic clamp, increases leptin secretion from isolated human abdominal adipocytes and serum concentrations of leptin in lean humans (16). The question, however, is whether a decrease in insulin concentrations in women can result in a reduction in leptin secretion.

In a recent study, in which women with PCOS were treated for 3 months with the insulin-sensitizing agent troglitazone, leptin levels did not change significantly despite the significant decrease in insulin concentrations (9). However, several explanations may be relevant to the results of that study, such as, for instance, that a direct action of troglitazone might have counterbalanced the effect of insulin on leptin secretion and, therefore, the possibility that a reduction in insulin values may result in a reduction of leptin production cannot be excluded. The present study is the first which shows a concomitant decrease in insulin and leptin concentrations in women with PCOS as a result of a single drug administration. The significant positive correlations which were found between leptin and insulin concentrations before and after treatment with diazoxide could easily support the assumption that insulin was responsible for the reduction in leptin secretion. However, it should be emphasized that when multiple regression analysis was performed no such correlation was found, apart from the significant positive correlation between leptin and BMI, as in previous studies, most probably due to the small number of patients. In the present, as in previous studies (6-10), leptin concentrations correlated significantly and positively with BMI and insulin concentrations in women with PCOS. Therefore, the significant correlation between insulin and BMI in this study could be responsible for the correlation between leptin and insulin $(7,8,10)$. Nevertheless, it should be taken into account that other investigators (8) have shown that insulin can affect leptin levels independently of BMI. Whether hyperglycaemia induced by diazoxide could further confound the analysis of the data is not likely, because leptin values did not correlate with sum glucose values in this study and because of the lack of correlation between leptin and fasting glucose in a previous study (8). Despite the above limitations, one cannot exclude the possibility that the decrease in insulin concentrations in the present study contributed to the reduction in leptin levels, but before a cause and effect relationship between the two substances is established further investigation is required. Furthermore, we cannot exclude the possibility that diazoxide itself exerted a direct effect on leptin secretion, as it did on insulin secretion, but this needs to be investigated further.

In the present study, apart from the reduction in leptin and insulin concentrations after treatment with diazoxide, other hormonal parameters, such as free testosterone, $\Delta 4$ androstenedione, IGF-I and SHBG were also influenced. The reduction of androgens which was found could be attributed to the decrease of insulin levels (20). The possibility that the reduction in androgens contributed to the reduction in leptin values is not likely, since in agreement with previous studies $(6,7,9,10)$ no significant correlations were found between leptin and androgens or SHBG concentrations, although one study in normal women has shown a positive correlation between leptin and free testosterone levels (6). So far, there is no indication that androgens might regulate the secretion of leptin in vivo or in vitro. Finally, the correlation which was found in this study between leptin and IGFBP-3 is difficult to explain, although the concentrations of this protein did not change after the administration of diazoxide to the 
women. That IGFBP-3 did not follow the reduction of insulin could be related to a differential effect of diazoxide on insulin and IGFBP-3, since it is known that there is no relationship between IGFBP-3 and the serum insulin levels (21).

Another finding in the present study was the negative correlations between leptin concentrations and those of pituitary gonadotrophins in women with PCOS before treatment with diazoxide. These correlations, however, were not significant, possibly due to the small number of patients, although a coefficient of correlation of 0.6 was found. Previous studies have also investigated the relationship between leptin and gonadotrophins and have found either no association $(6,7)$ or a negative correlation between leptin and $24 \mathrm{~h}$ mean LH levels or $24 \mathrm{~h}$ mean LH pulse amplitude (8). When in the latter study (8), BMI was taken into account, the relationship between leptin and LH concentrations was not significant. Nevertheless, since administration of leptin to $o b / o b$ mice, lacking endogenous leptin, increases serum $\mathrm{LH}$ concentrations and the weight of the ovaries and the uterus (5), it is possible that leptin under specific conditions may interfere with the function of the pituitary-ovarian axis (22). Recently, receptors of leptin have been found in the ovaries $(23,24)$ and leptin can directly affect gonadal steroid secretion from granulosa cells in vitro (23). Also, in vivo data have shown increased values of leptin in the luteal as compared with the follicular phase of the cycle in normal women (25).

In conclusion, the results of the present study demonstrate for the first time that administration of diazoxide in patients with PCOS induces a significant reduction in serum leptin concentrations. Although the mechanism of this reduction is unclear, it is suggested that the concomitant decrease of insulin levels may play a role.

\section{References}

1 Zhang Y, Proenca R, Maffei M, Barone M, Leopold L \& Friedman JM. Positional cloning of the mouse obese gene and its human homologue. Nature 1994372 425-432.

2 Caro JF, Sinha MK, Kolaczynski JW, Zhang PL \& Considine RV. Leptin: the tale of an obesity gene. Diabetes 199645 1455-1462.

3 Halaas JL, Gajawala KS, Maffei M, Cohen SL, Chait BT, Rabinowitz $\mathrm{D}$ et al. Weight-reducing effects of the plasma protein encoded by the obese gene. Science $1995269543-546$.

4 Pelleymounter MA, Cullen MJ, Baker MB, Hecht R, Winters D, Boone $\mathrm{T}$ et al. Effects of the obese gene product on body weight regulation in ob/ob mice. Science $1995269540-543$.

5 Barash IA, Cheung CC. Weigle DS, Ren H, Kabigting EE, Kuijper JL et al. Leptin is a metabolic signal to the reproductive system. Endocrinology 1996137 3144-3147.

6 Brzechffa PR, Jakimiuk AJ, Agarwal SK, Weitsman SP, Buyalos RP \& Magoffin DA. Serum immunoreactive leptin concentrations in women with polycystic ovary syndrome. Journal of Clinical Endocrinology and Metabolism 199681 4166-4169.

7 Chapman IM, Wittert GA \& Norman RJ. Circulating leptin concentrations in polycystic ovary syndrome: relation to anthropometric and metabolic parameters. Clinical Endocrinology 1997 46 175-181.
8 Laughlin GA, Morales AJ \& Yen SSC. Serum leptin levels in women with polycystic ovary syndrome: the role of insulin resistance/hyperinsulinemia. Journal of Clinical Endocrinology and Metabolism 199782 1692-1696.

9 Mantzoros CS, Dunaif A \& Flier JS. Leptin concentrations in the polycystic ovary syndrome. Journal of Clinical Endocrinology and Metabolism 199782 1687-1691.

10 Rouru J, Anttila L, Koskinen P, Penttila T-A, Irjala K, Huupponen $\mathrm{R}$ et al. Serum leptin concentrations in women with polycystic ovary syndrome. Journal of Clinical Endocrinology and Metabolism 199782 1697-1700.

11 Spicer LJ \& Echternkamp SE. The ovarian insulin and insulin-like growth factor system with an emphasis on domestic animals. Domestic Animal Endocrinology 199512 223-245.

12 Goldzieher JW. Polycystic ovarian disease. Fertility and Sterility $198135371-395$.

13 Fajans SS \& Floyd JC Jr. Diagnosis and medical management of insulinomas. Annual Review of Medicine 197930 313-329.

14 Adams J, Polson DW \& Franks S. Prevalence of polycystic ovaries in women with anovulation and idiopathic hirsutism. British Medical Journal 1986293 355-359.

15 Blum WF, Englaro P, Hanitsch S, Juul A, Hertel NT, Muller J et al. Plasma leptin levels in healthy children and adolescents: dependence on body mass index, body fat mass, gender, pubertal stage and testosterone. Journal of Clinical Endocrinology and Metabolism 199782 2904-2910.

16 Kolaczynski JW, Nyce MR, Considine RV, Boden G, Nolan JJ, Henry R et al. Acute and chronic effect of insulin on leptin production in humans - studies in vivo and in vitro. Diabetes $199645699-701$.

17 Hardie LJ, Rayner DV, Holmes S \& Trayhurn P. Circulating leptin levels are modulated by fasting, cold exposure and insulin administration in lean but not Zucker (fa/fa) rats as measured by ELISA. Biochemical and Biophysical Research Communications $1996223660-665$.

18 Dagogo-Jack S, Fanelli C, Paramore D, Brothers J \& Lardt M. Plasma leptin and insulin relationships in obese and nonobese humans. Diabetes 199645 695-698.

19 Korbonits M, Trainer PJ, Little JA, Edwards R, Kopelmar PG, Besser GM et al. Leptin levels do not change acutely with food administration in normal or obese subjects but are negatively correlated with pituitary-adrenal activity. Clinical Endocrinology $199746751-757$.

20 Nestler JE, Barlascini CO, Matt DW, Steingold KA, Plymate SR, Clore JN et al. Suppression of serum insulin by diazoxide reduces serum testosterone levels in obese women with polycystic ovary syndrome. Journal of Clinical Endocrinology and Metabolism 1989 68 1027-1032.

21 Baxter RC \& Cowell CT. Diurnal rhythm of growth hormoneindependent binding protein for insulin-like growth factors in human plasma. Journal of Clinical Endocrinology and Metabolism $198765432-440$.

22 Chehab FF, Lim ME \& Lu R. Correction of the sterility defect in homozygous obese female mice by treatment with the human recombinant leptin. Nature Genetics 199612 318-320.

23 Cioffi JA, Shafer AW, Zupancic TJ, Smith-Gbur J, Mikhail A, Platika D et al. Novel B219/OB receptor isoforms: possible role of leptin in hematopoiesis and reproduction. Nature Medicine 19962 585-589.

24 Spicer LJ \& Francisco CC. The adipose obese gene product, leptin: evidence of a direct inhibitory role in ovarian function. Endocrinology 1997138 3374-3379.

25 Hardie L, Trayhurn P, Abramovich D \& Fowler P. Circulating leptin in women: a longitudinal study in the menstrual cycle and during pregnancy. Clinical Endocrinology 199747 101-106.

Received 23 December 1997

Accepted 4 May 1998 